\title{
HAKIKAT EVALUASI: Perspektif Filsafat Pendidikan Islam
}

Oleh: Nuryamin*

\begin{abstract}
Generally in education and especially in school, assessment is meaningful to students, teachers and school it self. For students, there are two possibilities may occur, satisfied or unsatisfied. For teachers, it can be used to know whether or not student master the teaching material. It is also used to know whether or not the teaching method is effective. It may be argued that the teaching method and media are ineffective when most students get lower score. Finally, for school, evaluation may become a basis of improving good learning condition as a prerequisite of qualified school.
\end{abstract}

KEYWORDS: evaluation, satisfies, mastery, Method, qualified.

UNTUK mengetahui apakah tujuan yang dirumuskan dapat tercapai, apakah aktivitas yang dilakukan telah berhasil mencapai sasaran, apakah prosedur kerja yang dilakukan sudah tepat, apakah sumber daya yang dimiliki sudah dapat dimobilisasi secara optimal untuk mencapai tujuan, apakah elemen-elemen pendukung kegiatan sudah berfungsi dengan baik, kesemuanya itu membutuhkan proses evaluasi untuk dapat menjawab secara tepat. ${ }^{1}$ Sebagaimana pentingnya penetapan atau perumusan tujuan, pentingnya aktivitas dalam suatu kegiatan, maka kedudukan evaluasi dalam proses kegiatan juga memiliki kedudukan yang sama pentingnya, karena evaluasi merupakan bagian integral dari proses kegiatan secara keseluruhan. Karena itu secara sederhana evaluasi akan menjadi wahana untuk mengetahui tingkat keberhasilan dari keseluruhan aktivitas yang dilakukan serta menjadi sumber informasi yang terukur hambatanhambatan atau kendala yang dihadapi di dalam proses pencapaian tujuan yang telah dirumuskan.

Evaluasi dalam proses belajar mengajar merupakan komponen yang penting dan tidak dapat dipisahkan dari keseluruhan proses. Kepentingan evaluasi tidak hanya mempunyai makna bagi proses belajar siswa, tetapi

*Kandidat Doktor dalam Bidang Pendidikan dan Keguruan pada Program Pascasarjana UIN Alauddin ini adalah Dosen Tetap Fakultas Tarbiyah dan Keguruan UIN Alauddin Makassar 
juga memberikan umpan balik terhadap program secara keseluruhan. Oleh karena itu, inti evaluasi adalah pengadaan informasi bagi pihak pengelola proses belajar mengajar untuk membuat macam-macam keputusan.

Untuk mengetahui kepentingan evaluasi, dapat dilihat pandangan Abuddin Nata berikut ini:

1. Untuk mengetahui tercapai tidaknya tujuan instruksional secara komprehensif yang meliputi aspek pengetahuan, sikap, dan tingkah laku.

2. Sebagai umpan balik yang berguna bagi tindakan berikutnya di mana segi-segi yang sudah dapat dicapai lebih ditingkatkan lagi dan segi-segi yang dapat merugikan sebanyak mungkin dihindari.

3. Bagi pendidik, evaluasi berguna untuk mengukur keberhasilan proses belajar mengajar; bagi peserta didik berguna untuk mengetahui bahan pelajaran yang diberikan dan dikuasainya; dan bagi masyarakat untuk mengetahui berhasil atau tidaknya program-program yang dilaksanakan.

4. Untuk memberikan umpan balik kepada guru sebagai dasar untuk memperbaiki proses belajar mengajar dan mengadakan program remedial bagi murid.

5. Untuk menentukan angka kemajuan atau hasil belajar.

6. Untuk menempatkan murid dalam situasi belajar mengajar yang tepat.

7. Untuk mengenal latar belakang murid yang mengalami kesulitankesulitan belajar. ${ }^{2}$

Dari pandangan tersebut di atas memberikan gambaran yang jelas bahwa setiap kegiatan belajar mengajar dapat diketahui hasilnya melalui evaluasi. Evaluasi mutlak dilakukan dan merupakan kewajiban setiap guru. Dikatakan kewajiban bagi setiap guru karena pada akhirnya guru harus dapat memberikan informasi kepada lembaganya ataupun kepada anak didik itu sendiri, bagaimana dan sampai di mana penguasaan dan kemampuan yang telah dicapai anak didik tentang materi dan keterampilan-keterampilan mengenai mata ajaran yang telah diberikan.

\section{PERMASALAHAN}

Berdasarkan latar belakang masalah di atas, dapat dikemukakan beberapa rumusan masalah yang menjadi patokan dalam penulisan makalah ini, yakni: hakekat evaluasi dalam pendidikan Islam.

1. Bagaimana teori hakekat?

2. Bagaimana pengertian evaluasi?

3. Bagaimana prinsip-prinsip evaluasi dalam pendidikan Islam?

4. Bagaimana hakekat fungsi dan tujuan evaluasi dalam pendidikan Islam? 


\section{HAKEKAT EVALUASI}

\section{Teori Hakekat}

Berbicara tentang hakekat berarti berbicara tentang teori keberadaan, dan hasil berpikir tentang segala sesuatu yang ada dan mungkin ada telah terkumpul banyak. Nama lain untuk teori hakikat ialah teori tentang keadaan, demikian pandangan Langevel sebagaimana dikutip Ahmad Tafsir. ${ }^{3}$

Hakekat adalah realitas, yakni ke-real-an; "real" artinya kenyataan yang sebenarnya. Hakekat adalah kenyataan yang sebenarnya, keadaan sebenarnya sesuatu, bukan keadaan sementara atau keadaan yang menipu, bukan keadaan yang berubah. ${ }^{4}$ Suatu pengandaian, bahwa pada hakekatnya pemerintahan demokratis menghargai pendapat rakyat. Mungkin orang pernah menyaksikan pemerintahan itu melakukan tindakan sewenang-wenang, tidak menghargai pendapat rakyat. Itu hanyalah keadaan sementara, bukan hakiki. Yang hakiki pemerintahan itu demokratis. Melihat suatu obyek fatamorgana, ia tidak real karena tidak ada. Karena itu fatamorgana itu bukan hakekat.

Bahasa lain dari teori hakekat adalah ontologi. Ontologi dalam bahasa Inggeris "ontology" berakar dari bahasa Yunani "on" berarti ada, dan ontos berarti keberadan. Sedangkan "logos" berarti pemikiran. ${ }^{5}$ Jadi ontologi adalah pemikiran mengenai yang ada dan keberadaannya. Sedangkan menurut A.R. Lacey sebagaimana dikutip Suparlan bahwa ontologi diartikan sebagai "a central part of metaphisics". 6 Sedangkan metafisika diartikan sebagai "that which comes after 'physics' yakni hal yang hadir setelah fisika. Dalam metafisika, pada dasarnya dipersoalkan mengenai substansi atau hakekat yang ada.

Karakteristik ontologi, seperti diungkapkan oleh Bagus, antara lain dapat disederhanakan sebagai berikut:

1. Ontologi adalah studi tentang arti "ada" dan "berada", tentang ciri-ciri esensial dari yang ada dalam dirinya sendiri, menurut bentuknya yang paling abstrak.

2. Ontologi adalah cabang filsafat yang mempelajari tata dan struktur realitas dalam arti seluas mungkin, dengan menggunakan ketegorikategori seperti: ada atau menjadi, aktualitas atau potensialitas, nyata atau penampakan, esensi atau eksistensi, kesempurnaan, ruang dan waktu, perubahan, dan sebagainya.

3. Ontologi adalah cabang filsafat yang mencoba melukiskan hakekat terakhir yang ada, yaitu Yang Satu, Yang Absolut, Bentuk Abadi, Sempurna, dan keberadaan segala sesuatu yang mutlak bergantung kepadaNya. 
4. Cabang filsafat yang mempelajari tentang status realitas apakah nyata atau semu, apakah pikiran itu nyata, dan sebagainya. ${ }^{7}$

Dari pandangan di atas dapat dipahami bahwa yang ada itu ada yang bersifat fisik dan ada pula yang bersifat metafisika. Metafisika itulah yang menjadi obyek kajian filsafat. Walaupun diketahui bahwa obyek ilmu pengetahuan itu ada yang berupa materi (obyek materi) ${ }^{8}$ dan ada yang berupa bentuk (obyek forma). ${ }^{9}$ Obyek forma atau cara pandang ini berkonsentrasi pada satu segi saja, sehingga menurut segi yang satu ini kemudian tergambarlah lingkup suatu pengetahuan mengenai sesuatu hal menurut segi tertentu.

Di dalam metafisika, dijelaskan bahwa mengenai segala yang ada ini berada di dalam tiga dimensi, yaitu dimensi abstrak (abstrack being), kemungkinan (potentiality being) dan perwujudan (appearance being). ${ }^{10}$ Berada di dalam dimensi abstrak menentukan segala hal yang ada secara plural di dalam sifat universal, yakni di dalam satu kesamaan jenis. Segala yang ada juga berada di dalam potensi sendiri-sendiri, meskipun dalam kesatuan jenis. Dengan potensinya itu, yang ada menjadi berada di dalam pribadinya sendiri, yakni di dalam kepribadiannya sendiri. Kemudian segala sesuatu berada di dalam dimensi konkret yang menentukan cara penampakan atau perwujudan sebagai individu yang keberadaannya terikat dalam ruang dan waktu tertentu. Sebagai individu, setiap hal mengalami segala macam perubahan dan perkembangan, sehingga berbeda dan terpisah dengan yang lain. Oleh sebab itu dapat dipahami dan dinilai bahwa setiap hal yang ada, niscaya berada di dalam hakekat abstrak, hakekat pribadi dan hakekat konkret.

Di samping itu, menurut cara-cara keberadaannya, segala yang ada bisa berada di dalam angan-angan (imagination), di dalam kemungkinan (possibility), dan bisa juga di dalam kenyataan konkret (concrete fact).

\section{Evaluasi}

Setelah membicarakan teori hakekat, kemudian dihubungkan dengan evaluasi dalam filsafat pendidikan Islam, maka tergambarlah di dalam pikiran bahwa salah satu ciri penyelidikan filsafat adalah bersifat radikal, yakni penyelidikan yang mendalam, menukik sampai kepada inti atau akar permasalahan dan menyeluruh tentang evaluasi belajar dan pembelajaran.

Dalam evaluasi pendidikan, ada empat komponen saling terkait dan merupakan satu kesatuan yang tidak terpisahkan. Artinya, kegiatan evaluasi harus melibatkan kegiatan lainnya, yaitu penilaian, pengukuran dan tes (nontes). 


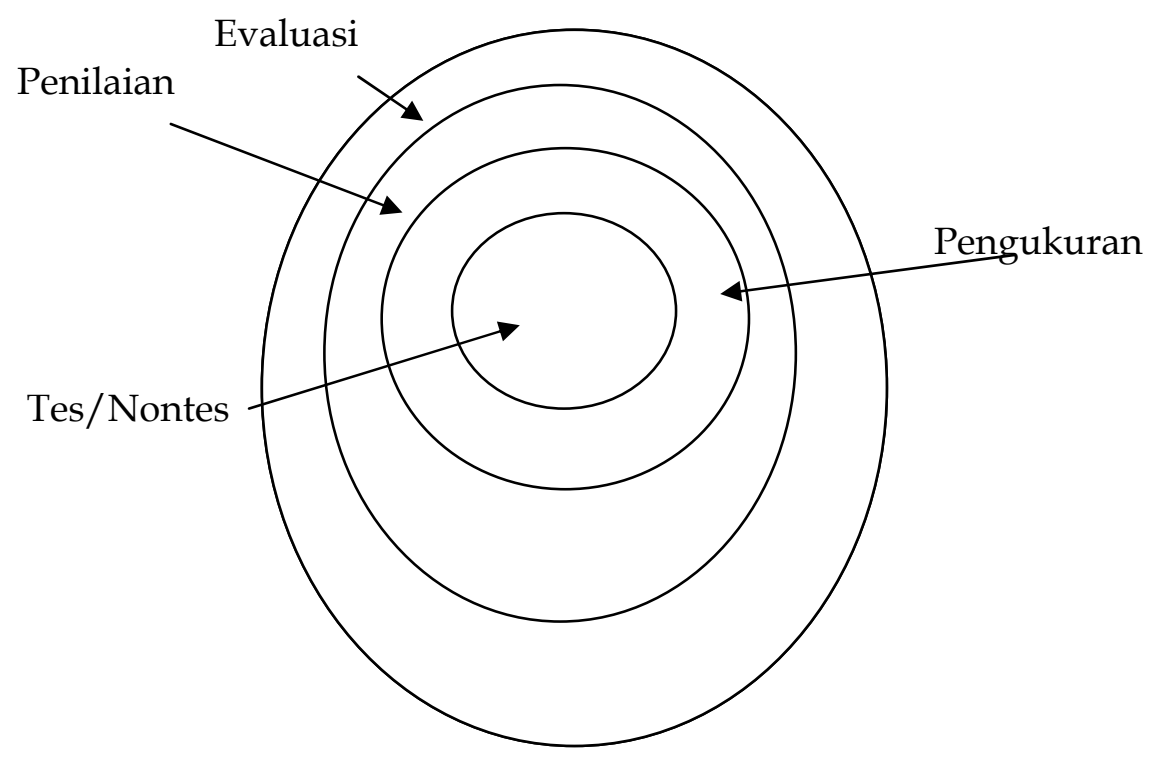

Komponen Evaluasi Pendidikan

Dalam mendefinisikan evaluasi, secara harfiah berasal dari bahasa Inggeris evaluation; dalam bahasa Arab: al-Taqdir (التقد ير); dalam bahasa Indonesia berarti: Penilaian. Akar katanya adalah value; dalam bahasa Arab: (al-Qimah: القيمة). Dengan demikian secara harfiah, evaluasi pendidikan dapat diartikan sebagai penilaian dalam bidang pendidikan atau hal-hal yang berkenaan dengan kegiatan pendidikan. ${ }^{11}$

Dari segi istilah para ahli memiliki sudut pandang yang berbeda, sesuai dengan bidang keahlian masing-masing. Namun muara pada semua definisi menuju ke suatu titik, yaitu proses penetapan keputusan tentang susuatu obyek yang dievaluasi. Dalam bidang pendidikan akan banyak bercerita dan berkaitan dengan masalah pendidikan seperti kinerja, prestasi, manajemen kelas, kompetensi guru, iklim akademis dan seterusnya.

Dalam konteks pendidikan, khususnya berkaitan dengan hasil kerja siswa, Nitko dan Brookhart sebagaimana dikutip Mansyur (dkk.) mendefinisikan evaluasi sebagai suatu proses penetapan nilai yang berkaitan dengan kinerja dan hasil karya siswa. Fokus evaluasi dalam kontekas ini adalah individu, yaitu prestasi belajar yang dicapai kelompok siswa atau kelas. ${ }^{12}$ Sudut pandang ini melihat bahwa evaluasi merupakan suatu proses penentuan sejauh mana tujuan pendidikan telah tercapai. Konsekuensi logis dari pandangan ini, mengharuskan evaluator untuk mengetahui betul tentang tujuan yang ingin dievaluasi. ${ }^{13}$ 
Dalam pandangan Edwind Wandt dan Gerald W. Brown sebagaimana dikutip Anas Sudijono: evaluasi menunjuk kepada atau mengandung pengertian suatu tidakan atau suatu proses untuk menentukan nilai dari sesuatu. ${ }^{14}$

Evaluasi pendidikan sebagai suatu tindakan atau kegiatan yang dilaksanakan dengan maksud untuk- atau suatu proses- yang berlangsung dalam rangka- menentukan nilai dari segala sesuatu yang berhubungan dengan, atau yang terjadi di lapangan pendidikan. Atau singkatnya evaluasi pendidikan adalah kegiatan atau proses penentuan nilai pendidikan, sehingga dapat diketahui mutu atau hasil-hasilnya.

Menurut Phopan bahwa, untuk memahami arti evaluasi terlebih dahulu memahami arti pengukuran. Menurutnya pengukuran menunjukkan kegiatan mengukur, yaitu menghitung atau menetapkan angka-angka sehingga dapat menggambarkan sesuatu secara lebih seksama, seberapa besarnya, kecilnya, panjangnya, dan sebagainya. Penetapan status gejala tertentu dengan cara yang lebih seksama, misalnya mengetahui tinggi rendahnya pengetahuan siswa tentang perkalian, dengan mengukur pengetahuan mereka melalui ujian. Siswa-siswa tertentu dapat menjawab $90 \%$ dari soal yang diberikan, sedang siswa-siswa lainnya hanya mampu menyelesaikan $10 \%$, dari itu ada gambaran yang lebih pasti tentang pengetahuan perkalian siswa-siswa. ${ }^{15}$ Di dalam pengukuran tersebut tidak sejenakpun diharuskan membuat pertimbangan nilai tentang kebaikan maupun keburukan prestasi siswa karena pengukuran hanya berurusan dengan pemerian bukan menilai fenomena yang diperlukan.

Michael Scripen, seorang teoritisi evaluasi mengamati bahwa evaluasi terdiri dari penetapan nilai. Karena itu evaluasi pendidikan terdiri dari penetapan nilai sehubungan dengan fenomena pendidikan. Penetapan nilai yang dimaksudkan adalah penentuan manfaat atau kebaikan relatif dari segala sesuatu yang dievaluasi. ${ }^{16}$

Pengertian istilah evaluasi pendidikan dapat juga dilihat dari Lembaga Administrasi Negara adalah:

1. Proses/kegiatan untuk menentukan kemajuan pendidikan, dibandingkan dengan tujuan yang telah ditentukan.

2. Usaha untuk memperoleh informasi berupa umpan balik (feed back) bagi penyempurnaan pendidikan. ${ }^{17}$

Kegiatan pendidikan atau proses belajar-mengajar di sekolah diumpamakan sebagai tempat mengolah sesuatu dan siswa diumpamakan sebagai bahan mentah, maka lulusan dari sekolah itu dapat disamakan dengan hasil olahan yang sudah siap digunakan. Dalam istilah inovasi yang menggunakan teknologi maka tempat pengolah ini disebut transformasi. 
Jika digambarkan dalam bentuk diagram akan terlihat sebagai berikut:

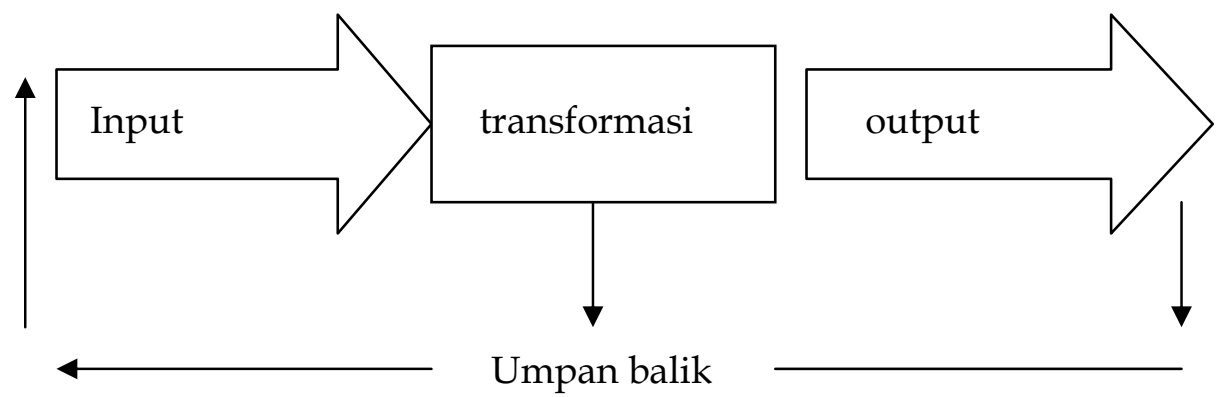

- Input, adalah bahan mentah yang dimasukkan kedalam transformasi. Dalam sekolah maka yang dimaksud dengan bahan mentah adalah calon siswa yang baru akan memasuki sekolah. Sebelum memasuki suatu tingkat sekolah (institusi), dinilai dahulu kemampuannya. Dengan penilaian itu ingin diketahui apakah kelak ia akan mampu mengikuti pelajaran dan melaksanakan tugas-tugas yang akan diberikan kepadanya.

- Output, adalah bahan jadi yang dihasilkan oleh transformasi. Yang dimaksudkan adalah siswa lulusan sekolah yang bersangkutan. Untuk dapat menentukan apakah seorang siswa berhak lulus atau tidak, perlu diadakan kegiatan penilaian.

- Transformasi, adalah mesin yang bertugas mengubah bahan mentah menjadi bahan jadi. Dalam dunia sekolah, sekolah itulah yang dimaksud transformasi. ${ }^{18}$ Sekolah itu sendiri terdiri dari beberapa mesin yang menyebabkan berhasil atau gagalnya sebagai transformasi. Bahan jadi yang diharapkan yakni siswa lulusan sekolah ditentukan oleh beberapa faktor sebagai akibat bekerjanya unsur-unsur yang ada. Unsur-unsur yang ada antara lain:

a. Guru dan personal lainnya.

b. Bahan pelajaran.

c. Metode mengajar dan sistem evaluasi.

d. Sarana penunjang.

e. Sistem administrasi.

- Umpan balik (feed back), adalah segala informasi baik yang meyangkut output maupun transformasi. Umpan balik ini diperlukan sekali untuk memperbaiki input maupun transformasi. Lulusan yang kurang bermutu atau yang belum memenuhi harapan, akan menggugah semua pihak untuk mengambil tindakan yang berhubungan dengan penyebab kurang bermutunya lulusan. 
Rangkaian akhir dari suatu proses kependidikan Islam adalah evaluasi. Berhasil atau tidaknya pendidikan Islam dalam mencapai tujuannya dapat dilihat setelah dilakukan evaluasi terhadap output yang dihasilkannya. Karena itu secara umum dapat dikemukakan kegunaan evaluasi dalam pendidikan Islam. Pertama, dari segi pendidik, evaluasi berguna untuk membantu seorang pendidik mengetahui sudah sejauh mana hasil yang dicapai dalam pelaksanaan tugasnya. Kedua, dari segi peserta didik, evaluasi berguna membantu peserta didik untuk dapat mengubah atau mengembangkan tingkah lakunya secara sadar ke arah yang lebih baik. Ketiga, dari segi ahli pikir pendidikan Islam, evaluasi berguna untuk membantu para pemikir pendidikan Islam mengetahui kelemahan teori-teori pendidikan Islam dan membantu mereka dalam merumuskan kembali teori-teori pendidikan Islam yang relevan dengan arus dinamika zaman yang senantiasa berubah. Keempat, dari segi politik pengambil kebijakan pendidikan Islam (pemerintah), evaluasi berguna untuk membantu mereka dalam membenahi sistem pengawasan dan mempertimbangkan kebijakan yang akan diterapkan dalam sistem pendidikan Nasional (Islam). ${ }^{19}$

Kegunaan tersebut dimaksudkan untuk mengetahui kebaikan dan kelemahan pendidikan Islam dalam berbagai aspeknya dalam rangka peningkatan kualitasnya ke masa depan. Hal ini berarti bahwa proses evaluasi dalam pendidikan Islam memiliki umpan balik (feed back) yang positif sifatnya ke arah perbaikan pendidikan Islam.

\section{PRINSIP-PRINSIP EVALUASI DALAM PENDIDIKAN ISLAM}

Penilaian dilaksanakan secara terpadu dengan kegiatan pembelajaran. Penilaian dapat dilakukan baik dalam suasana formal maupun informal, di dalam kelas, di luar kelas, terintegrasi dalam kegiatan belajar mengajar atau dilakukan pada waktu yang khusus. Penilaian dilaksanakan melalui berbagai cara, seperti tes tertulis, penilaian hasil kerja siswa melalui kumpulan hasil kerja (karya) siswa (fortofolio), dan penilaian unjuk kerja (perfomance) siswa. ${ }^{20}$

Untuk melaksanakan kegiatan secara terpadu perlu diperhatikan beberapa prinsip sebagai dasar pelaksanaan penilaian. Prinsip-prinsip tersebut adalah:

1. Penilaian hendaknya didasarkan atas hasil pengukuran yang komprehensif, yaitu pengkuran yang meliputi aspek kognitif, afektif, dan psikomotorik.

2. Penilaian harus dibedakan antara penskoran dengan angka dan penilaian dengan kategori. Penskoran berkenaan dengan aspek kuantitatif (dapat dihitung), dan penilaian berkenaan dengan aspek-aspek kualitatif (mutu). 
3. Pemberian nilai hendaknya merupakan bagian integral dari proses belajar mengajar.

4. Penilaian hendaknya bersifat komparabel artinya dapat dibandingkan antara satu tahap penilaian dengan tahap penilaian lainnya.

5. Sistem penilaian yang dipergunakan hendaknya jelas bagi siswa dan bagi pengajar sendiri, sehingga tidak membingunkan. ${ }^{21}$

Penilaian tersebut dapat berhasil jika dilakukan dengan prinsip-prinsip sebagai berikut:

a. Prinsip kesinambungan (kontinuitas); penilaian hendaknya dilakukan secara berkesinambungan

b. Prinsip menyeluruh, maksudnya penilaian harus mengumpulkan data mengenai seluruh aspek kepribadian

c. Prinsip obyektif, penilaian diusahakan agar seobyektif mungkin.

d. Prinsip sistematis, yakni penilaian harus dilakukan secara sistematis dan teratur. ${ }^{22}$

Betapapun baiknya prosesdur evaluasi diikuti dan sempurnanya tehnik evaluasi diterapkan, apabila tidak dipadukan dengan prinsip-prinsip penunjangnya, maka hasil evaluasi pun kurang dari yang diharapkan, demikian pandangan Daryanto. ${ }^{23}$ Karena itu, perlu kiranya diperhatikan berikut ini:

1. Keterpaduan, Evaluasi merupakan komponen integral dalam program pengajaran di samping tujuan instruksional dan materi serta metode pengajaran. Materi, metode dan evaluasi tiga kesatuan terpadu yang tidak boleh dipisahkan.

2. Keterlibatan siswa, hal ini berkaitan erat dengan metode belajar (Cara Belajar Siswa Aktif) yang menuntut keterlibatan siswa secara aktif. Untuk dapat mengetahui sejauh mana siswa berhasil dalam kegiatan belajar mengajar yang dijalaninya secara aktif, siswa membutuhkan evaluasi. Dengan demikian, evaluasi bagi siswa merupakan kebutuhan, bukan sesuatu yang harus dihindari.

3. Koherensi, dimaksudkan evaluasi harus berkaitan dengan materi pengajaran yang sudah disajikan dan sesuai dengan ranah kemampuan yang hendak diukur. Tidak dapat dibenarkan menyusun alat evaluasi hasil belajar atau evaluasi pencapaian belajar yang mengukur bahan yang belum disajikan dalam kegiatan belajar mengajar.

4. Pedagogis. Evaluasi perlu diterapkan sebagai upaya perbaikan sikap dan tingkah laku ditinjau dari segi pedagogis. Evaluasi dan hasilnya hendaknya dapat dipakai sebagai alat motivasi untuk siswa dalam kegiatan belajarnya. Hasil evaluasi hendaknya dirasakan sebagai ganjaran (reward) yakni sebagai penghargaan bagi yang berhasil, tetapi merupakan hukuman bagi yang tidak/kurang berhasil. 
5. Akuntabilitas. Sejauh mana keberhasilan program pengajaran perlu disampaikan kepada pihak-pihak yang berkepentingan dengan pendidikan sebagai laporan pertanggungjawaban (accountability). ${ }^{24}$

Persoalan yang dihadapi adalah sampai di manakah gambaran yang diperoleh tentang kemajuan anak didik?. Keadaan anak merupakan sesuatu yang sangat kompleks. Kalau hendak mengetahui keadaan anak, berarti hendak mengetahui segenap segmen kepribadiannya yang meliputi temperamen, waktu penyesuaian diri (adjusment)nya, pola minatnya, kecerdasan dan bakat-bakat yang ada pada diri anak.

Dengan memperhatikan prinsip-prinsip tersebut, memberikan gambaran tentang suatu penilaian yang menghasilkan manfaat untuk guru dan murid melalui penilaian kelas. Hein dan Price sebagaimana dikutip Mansyur dkk., menyatakan bahwa, apapun yang dikerjakan seorang siswa dalam kelas dapat digunakan untuk obyek penilaian. Ini berarti bahwa penilaian dapat terjadi pada setiap waktu. Tanggungjawab guru adalah untuk menggunakan pengalaman mengajar penuh arti sebagai pengalaman penilaian penuh arti. ${ }^{25}$

Agar penilaian kelas memenuhi tujuan ${ }^{26}$ dan fungsinya ${ }^{27}$ dapat dilihat beberapa prinsip berikut ini:

a) Mengacu ke kemampuan (competency referenced)

Penilaian kelas perlu disusun dan dirancang untuk mengukur apakah siswa telah menguasai kemampuan sesuai dengan target yang ditetapkan dalam kurikulum. Materi yang dicakup dalam penilaian kelas harus terkait secara langsung dengan indikator pencapaian kemampuan tersebut.

b) Berkelanjutan (continuous)

Penilaian yang dilakukan di kelas oleh guru harus merupakan proses yang berkelanjutan dalam rangkaian rencana mengajar guru selama satu semester dan tahun ajaran. Rangkaian aktivitas penilaian kelas yang dilakukan oleh guru melalui pemberian tugas, pekerjaan rumah (PR), ulangan harian, ulangan tengah dan akhir semester, serta akhir tahun ajaran merupakan proses yang berkesinambungan dan berkelanjutan selama satu tahun ajaran.

c) Didaktis

Alat yang akan digunakan untuk penilaian kelas berupa tes maupun non-tes harus dirancang baik isi, format, maupun tata letak (lay out) dan tampilannya agar siswa menyenangi dan menikmati kegiatan penilaian. Perancangan bahan penilaian yang kreatif dan menarik dapat mendorong siswa untuk menyelesaikan tugas penilaian, baik yang bersifat individual maupun kelompok dengan penuh antusias dan menyenangkan. 
d) Menggali Informasi

Penilaian kelas yang baik harus dapat memberikan informasi yang cukup bagi guru untuk mengambil keputusan dan umpan balik. Pemilihan metode, teknik dan alat penilaian yang tepat sangat menentukan jenis informasi yang ingin digali dari proses penilaian kelas. Acuan sederhana yang dapat digunakan guru adalah prinsip "sedikit-tapi banyak" (less-ismore). Prinsip ini dimaksudkan agar guru melakukan penilaian cakupan materi dan kemampuan yang tidak terlalu banyak tetapi informasi yang diperoleh dari hasil penilaian tersebut sangat dalam dan luas.

e) Melihat yang benar dan yang salah

Dalam melaksanakan penilaian, guru hendaknya melakukan analisis terhadap hasil penilaian dan kerja siswa secara seksama untuk melihat adanya kesalahan yang secara umum terjadi pada siswa sekaligus melihat hal-hal yang positif yang diberikan siswa. Hal-hal positif tersebut dapat berupa, misalnya, jawaban benar yang diberikan siswa di luar perkiraan atau cakupan yang ada pada guru. Siswa yang memiliki kecerdasan, pengetahuan dan pengalaman sangat mungkin memberikan jawaban dan penyelesaian masalah yang tidak tersedia pada bahan yang diajarkan di kelas. 28

Analisis terhadap kesalahan jawaban dan penyelesaian masalah yang diberikan siswa sangat berguna untuk menghindari terjadinya miskonsepsi dan ketidak jelasan dalam proses pembelajaran. Guru hendaknya memberikan penekanan terhadap kesalahan-kesalahan yang bersifat umum.

\section{TUJUAN DAN FUNGSI EVALUASI PENDIDIKAN ISLAM}

Pendidikan Islam secara rasional-filosofis adalah bertujuan untuk membentuk al-insān al-kamìl atau manusia paripurna. Beranjak dari konsep ini, pendidikan Islam hendaknya diarahkan pada dua dimensi, yaitu: pertama, dimensi dialektikal horizontal, kedua, dimensi ketundukan vertikal. ${ }^{29}$

Pada dimensi dialektikal horizontal pendidikan hendaknya dapat mengembangkan pemahaman tentang kehidupan konkrit yang terkait dengan diri, sesama manusia dan alam semesta. Untuk itu akumulasi berbagai pengetahuan, keterampilan dan sikap mental merupakan bekal utama dalam hubungannya dengan pemahaman tentang kehidupan konkrit tersebut. Sedangkan pada dimensi kedua, pendidikan sains dan teknologi, selain menjadi alat untuk memanfaatkan, memelihara dan melestarikan sumber daya alam, juga hendaknya menjadi jembatan dalam mencapai hubungan yang abadi dengan Sang Pencipta. ${ }^{30}$ 
Untuk itulah secara umum tujuan dan fungsi evaluasi pendidikan Islam diarahkan pada dua dimensi di atas, yakni sejauh mana pencapaian yang telah diperoleh pendidikan Islam dalam kaitannya dengan pembentukan al-insān al-kamìl.

Ajaran Islam yang menaruh perhatian yang besar terhadap evaluasi. Allah swt dalam berbagai firman-Nya dalam kitab suci Al-Qur'an menginformasikan bahwa, pekerjaan evaluasi merupakan suatu tugas penting dalam rangkaian proses pendidikan yang telah dilaksanakan oleh pendidik. Abuddin Nata mengutip (Q.S. al-Baqarah/2: 31-32) menyebut empat hal yang dapat diketahui. Pertama, Allah swt bertindak sebagai guru yang memberikan pelajaran kepada Nabi Adam as. Kedua, para malaikat tidak memperoleh pengajaran sebagaimana yang diterima Nabi Adam, mereka tidak dapat menyebutkan nama-nama benda. Ketiga, Allah swt meminta kepada Nabi Adam agar mendemonstrasikan ajaran yang diterimanya. Keempat, materi evaluasi, haruslah materi yang pernah diajarkannya. ${ }^{31}$

Selanjutnya Nabi Sulaiman pernah mengevaluasi kejujuran seekor burung hud-hud yang memberitahukan tentang adanya kerajaan yang diperintah oleh seorang wanita cantik, yang dikisahkan dalam yang berbunyi:

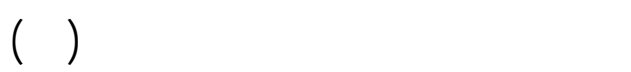

Berkata Sulaiman: Akan kami lihat (evaluasi) apakah kamu benar ataukah kamu termasuk orang-orang yang berdusta. ${ }^{32}$

Mendengar keterangan burung hud-hud, Nabi Sulaeman as. Tidak langsung mengambil keputusan untuk membenarkan atau mempersalahkannya. Karena itu, dalam rangka menguji kebenaran hud-hud, Nabi Sulaiman berkata: akan kami lihat, yakni menyelidiki dan memikirkan dengan matang, apakah engkau, wahai hud-hud, telah berkata benar tentang kaum Saba' itu ataukah engkau termasuk salah satu dari kelompok pera pendusta. ${ }^{33}$

Anas Sudijono merumuskan secara umum tujuan evaluasi pendidikan yakni:

a. Untuk menghimpun bahan-bahan keterangan yang akan dijadikan sebagai bukti mengenai taraf perkembangan atau taraf kemajuan yang dialami oleh para peserta didik, setelah mereka mengikuti proses pembelajaran dalam jangka waktu tertentu.

b. Untuk mengetahui tingkat efektifitas dari metode-metode pengajaran yang telah dipergunakan dalam proses pembelajaran selama jangka waktu tertentu. ${ }^{34}$ 
Secara khusus, tujuan pelaksanaan evaluasi dalam pendidikan Islam adalah untuk mengetahui kadar pemilikan dan pemahaman peserta didik terhadap materi pelajaran, baik dalam aspek kognitif, afektif dan psikomotorik. ${ }^{35}$

Evaluasi yang dilaksanakan secara berkesinambungan, akan membuka peluang bagi evaluator untuk membuka perkiraan (estimasi), apakah tujuan yang telah dirumuskan akan dapat dicapai pada waktu yang telah ditentukan, ataukah tidak. Apabila berdasar data hasil evaluasi itu diperkirakan bahwa tujuan tidak akan dapat dicapai sesuai dengan rencana, maka evaluator akan berusaha untuk mencari dan menemukan faktorfaktor penyebabnya, serta mencari dan menemukan jalan keluar atau caracara pemecahannya.

Dengan mengetahui makna penilaian ditinjau dari berbagai segi dalam sistem pendidikan, Suharsimi Arikunto merumuskan fungsi yang lebih spesifik antara lain :

1. Berfungsi selektif, dengan cara mengadakan penilaian guru mempunyai cara untuk mengadakan seleksi atau penilaian terhadap siswanya. Dengan penilaian itu sendiri mempunyai berbagai tujuan, antara lain:

a. Untuk memilih siswa yang dapat diterima di sekolah tertentu

b. Untuk memilih siswa yang dapat naik ke kelas atau tingkat berikutnya.

c. Untuk memilih siswa yang seharusnya mendapat beasiswa.

d. Untuk memilih siswa yang sudah berhak meninggalkan sekolah, dan sebagainya.

2. Berfungsi diagnostik, apabila alat yang digunakan dalam penilaian cukup memenuhi persyaratan, maka dengan melihat hasilnya, guru akan mengetahui kelemahan siswa. Di samping itu diketahui pula sebab musababnya kelemahan itu. Jadi dengan mengadakan penilaian, sebenarnya guru mengadakan diagnosa kepada siswa tentang kebaikan dan kelemahannya.

3. Berfungsi sebagai penempatan. Untuk dapat menentukan dengan pasti bahwa seorang siswa harus ditempatkan pada kelompok tertentu, maka digunakanlah suatu penilaian. Sekelompok siswa yang mempunyai hasil penilaian yang sama, akan berada dalam kelompok yang sama dalam belajar.

4. Berfungsi sebagai pengukur keberhasilan, yakni untuk mengetahui sejauhmana suatu program berhasil diterapkan. ${ }^{36}$

Dari fungsi-fungsi yang disebutkan di atas dapat ditarik dari tiga segi, yaitu: pertama, segi psikologis, bahwa kegiatan evaluasi akan memberikan pedoman atau pegangan batin kepada mereka untuk mengenal 
kapasitas dan status dirinya masing-masing di tengah-tengah kelompok atau kelasnya. Para siswa akan mengetahui apakah dirinya termasuk siswa yang berkemampuan tinggi, berkemampuan rata-rata, ataukah berkemampuan rendah.

Bagi pendidik, evaluasi akan memberikan kepastian atau ketetapan hati kepada diri pendidik tersebut, sudah sejauh manakah kiranya usaha yang telah dilakukannya selama ini telah membawa hasil, sehingga secara psikologis memiliki pedoman atau pegangan batin yang pasti guna menentukan langkah-langkah apa saja yang dipandang perlu dilakukan selanjutnya, kedua, secara didaktis akan dapat memberikan dorongan (motivasi) kepada mereka untuk dapat memperbaiki, meningkatkan dan mempertahankan prestasinya. Dan bagi pendidik, secara didaktis memiliki beberapa fungsi antara lain: a) memberikan landasan untuk menilai hasil usaha (prestasi) yang telah dicapai oleh peserta didiknya, b) memberikan informasi yang sangat berguna, guna mengetahui posisi masing-masing peserta didik di tengah-tengah kelompoknya, c) memberikan bahan yang penting untuk memilih dan kemudian menetapkan status peserta didik, d) memberikan pedoman untuk mencari dan menemukan jalan keluar bagi peserta didik yang memang memerlukannya, e) memberikan petunjuk tentang sudah sejauhmana program pengajaran yang telah ditentukan telah dapat dicapai, ketiga, secara administratif, setidaknya memiliki fungsi: a) memberikan laporan, b) memberikan bahan-bahan keterangan (data), c) memberi gambaran mengenai hasil-hasil yang telah dicapai dalam proses pembelajaran.

\section{SIMPULAN}

1. Hakekat evaluasi pendidikan Islam adalah konsep berpikir tentang penilaian dalam proses belajar mengajar yang mempunyai tujuan dan fungsi untuk mengetahui tingkat keberhasilan atau tidaknya tujuan pendidikan Islam (dengan seluruh komponen yang terlibat di dalamnya) dalam mencapai tujuan pendidikan yang dicita-citakan.

2. Dalam dunia pendidikan, khususnya dunia persekolahan, penilaian mempunyai makna bagi siswa, guru dan sekolah itu sendiri. Bagi siswa dua kemungkinan, memuaskan dan tidak memuaskan, sedangkan bagi guru akan dapat mengetahui siswa-siswa mana yang sudah menguasai atau yang belum menguasai pelajarannya. Demikian juga penggunaan metode yang tepat. Jika sebahagian besar dari siswa memperoleh angka jelek, maka boleh jadi penyebabnya adalah pendekatan atau metode yang kurang tepat. Sedangkan bagi sekolah adalah menciptakan kondisi belajar sebagai cermin sekolah yang berkualitas. 
3. Baik tujuan umum maupun tujuan khusus dari evaluasi pendidikan adalah merangsang kegiatan peserta didik dalam menempuh program pendidikan. Tanpa adanya evaluasi maka tidak mungkin timbul kegairahan atau rangsangan pada diri peserta didik untuk memperbaiki dan meningkatkan prestasinya masing-masing.

\section{CATATAN AKHIR}

1. Aunurrahman, Belajar dan Pembelajaran, cet. III, Bandung: Alfabeta, 2009, h. 203.

2. Lihat Abuddin Nata, Filsafat Pendidikan Islam, cet. I, Jakarta: Logos Wacana Ilmu, 1997, h. 135-136.

3. Ahmad Tafsir, Filsafat Umum Akal dan Hati Sejak Thales Sampai James, cet. I, Bandung: Remaja Rosdkarya, 1990, h. 31.

4. Ibid., h. 32.

5. Suparlan Suhartono, Filsafat Ilmu Pengetahuan Persoalan Eksistensi dan Hakekat Ilmu Pengetahuan, cet. I, Yogyakarta: Ar-Ruzz Media, 2008, h. 111.

6. Ontologi adalah bagian sentral dari metafisika, Ibid.

7. Ibid., h. 112.

8. Obyek materi adalah sasaran material suatu penyelidikan, pemikiran, atau penelitian keilmuan, bisa berupa benda-benda material maupun yang nonmaterial, bisa pula berupa hal-hal, masalah-masalah, ide-ide dan konsepkonsep. Obyek materi tidak terbatas pada apakah ada dalam realitas kongkret atau dalam realitas abstrak. Obyek materi, yang material maupun yang non material, sebenarnya merupakan suatu substansi yang tidak begitu saja dengan mudah diketahui. Lebih-lebih yang non material, sedang yang material pun sebagai suatu substansi mempunyai segi yang sulit dihitung dan ditentukan jumlahnya. Lihat Soetriono, Rita Hanafie, Filsafat Ilmu dan Metodologi Penelitian, Yoyakarta: Andi Offset, 2007, h. 13.

9. Sangat sulit untuk memahami maknanya, apalagi yang non-material. Karena itu ada pendekatan-pendekatan yang dilakukan orang secara cermat dan bertahap menurut segi-segi yang dimiliki obyek materi itu, dan tentu saja menurut kemampuan seseorang. Cara pendekatan inilah yang selanjutnya dikenal sebagai obyek forma.atau cara pandang. Lihat ibid.

10. Suparlan Suhartono, op. cit., h. 39.

11. Lihat Anas Sudijono, Pengantar Evaluasi Pendidikan, cet. III, Jakarta: Raja Grafindo Persada, 2001, h. 1.

12. Mansyur, Harun Rasyid dan Suratno, Asesmen Pembelajaran di Sekolah, cet. I Yogyakarta: Multi Pessindo, 2009, h. 7.

13. Beberapa hal yang dapat dijadikan sebagai obyek evaluasi dalam konteks ini yaitu prestasi belajar, sikap, perilaku, motivasi, motivasi diri, minat dan tanggungjawab. Lihat ibid.

14. Anas Sudijono, loc. cit.

15. Aunurrahman, op. cit., h. 205.

16. Ibid., h. 206.

17. Anas Sudijono, op. cit., h. 2. 
18. Suharsimi Arikunto, Dasar-Dasar Evaluasi Pendidikan, cet. V, Jakarta: Bina Aksara, 1989, h. 4.

19. Lihat Samsul Nazar, Filsafat Pendidikan Islam Pendekatan Historis, Teoritis dan Praktis, cet. I, Jakarta: Ciputat Pers, 2002, h. 78.

20. Ibid.

21. A. Tabrani Rusyan dkk., Pendekatan Dalam proses Belajar-Mengajar, cet. II, Bandung: Remaja Rosda Karya, 1992, h. 211-212. Bandingkan H. M. Sukardi, Evaluasi Pendidikan Prinsip dan Operasionalnya, cet. III, Jakarta: Bumi Aksara, 2009, h. $4-5$

22. Ibid.

23. Daryanto, Evaluasi Pendidikan, cet. II, Jakarta: Rineka Cipta, 2001, h. 19-21.

24. Suke Silverius, Evaluasi Hasil Belajar dan Umpan balik, Jakarta: Grasindo, 1991, h. 11-12.

25. Mansyur dkk., op. cit., h. 67.

26. Tujuan penilaian kelas hendaknya diarahkan pada empat tujuan berikut: 1) Penelusuran (keeping track), 2) Pengecekan (checking-up), 3) Pencarian(findingout), 4) Penyimpulan (summing-up). Lihat Abdul Majid, Perencanaan Pembelajaran Mengembangkan Standar Kompetensi Guru, cet. II, Bandung: PT. Remaja Rosdakarta, 2006, h. 187-188.

27. Fungsi motivasi, belajar tuntas, sebagai indikator efektifitas pengajaran dan sebagai fungsi umpan balik. Lihat Ibid.

28. Lihat Ibid., h. 190-191.

29. A.M. Saefuddin, et, al, Desekularisasi Pemikiran Landasan Islamisasi, Bandung: Mizan, 1991, h. 126.

30. Samsul Nizar, op. cit., h. 79.

31. Abuddin Nata, op. cit., h. 134-135.

32. Q.S. al-Naml/27:27.

33. Kisah lebih lengkap, baca M. Quraish Shihab, Tafsir Al-Misbah Pesan, Kesan, dan Keserasian al-Qur'an, Vol. 9, cet. I, Jakarta: Lentera Hati, 2009, h. 433.

34. Anas Sudijono, op. cit., h. 16

35. Merangsang kegiatan peserta didik dalam menempuh program pendidikan, serta mencari dan menemukan faktor-faktor penyebab keberhasilan dan ketidakberhasilan peserta didik dalam mengikuti program pendidikan, sehingga dapat dicari dan ditemukan jalan keluar atau cara-cara perbaikannya. Lihat Ibid., h. 17.

36. Lihat Suharsimi Arikunto, op. cit., h. 9-11. Lihat juga H. M. Sukardi, loc. cit.

\section{DAFTAR PUSTAKA}

Aunurrahman, Belajar dan Pembelajaran, cet. III; Bandung: Alfabeta, 2009.

Arikunto, Suharsimi, Dasar-Dasar Evaluasi Pendidikan, cet. V; Jakarta: Bina Aksara, 1989.

Daryanto, Evaluasi Pendidikan, cet. II, Jakarta: Rineka Cipta, 2001.

Hanafie, Rita Soetriono, Filsafat Ilmu dan Metodologi Penelitian, Yoyakarta: Andi Offset, 2007.

Mansyur, Harun Rasyid dan Suratno, Asesmen Pembelajaran di Sekolah, cet. I, Yogyakarta: Multi Pessindo, 2009. 
Majid, Abdul, Perencanaan Pembelajaran Mengembangkan Standar Kompetensi Guru cet. II, Bandung: PT. Remaja Rosdakarta, 2006.

Nata, Abuddin, Filsafat Pendidikan Islam, cet. I, Jakarta: Logos Wacana Ilmu, 1997.

Nizar, Samsul, Filsafat Pendidikan Islam Pendekatan Historis, Teoritis dan Praktis, cet. I, Jakarta: Ciputat Pers, 2002.

Rusyan, A. Tabrani dkk., Pendekatan Dalam proses Belajar-Mengajar, cet. II, Bandung: Remaja Rosda Karya, 1992.

Saefuddin, A.M., et, al,. Desekularisasi Pemikiran Landasan Islamisasi, Bandung: Mizan, 1991.

Shihab, M. Quraish, Tafsir Al-Misbah Pesan, Kesan, dan Keserasian al-Qur'an, Vol. 9, cet. I, Jakarta: Lentera Hati, 2009.

Silverius, Suke, Evaluasi Hasil Belajar dan Umpan balik, Jakarta: Grasindo, 1991.

Sudijono, Anas, Pengantar Evaluasi Pendidikan, cet. III, Jakarta: Raja Grafindo Persada, 2001.

Suhartono, Suparlan, Filsafat Ilmu Pengetahuan Persoalan Eksistensi dan Hakekat Ilmu Pengetahuan, cet. I, Jogjakarta: Ar-Ruzz Media, 2008.

Tafsir, Ahmad, Filsafat Umum Akal dan Hati Sejak Thales Sampai James, cet. I, Bandung: Remaja Rosdakarya, 1990. 